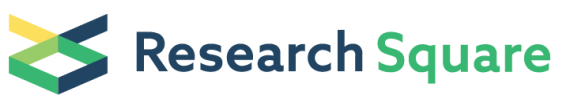 \\ Preprints are preliminary reports that have not undergone peer review. \\ They should not be considered conclusive, used to inform clinical practice, \\ or referenced by the media as validated information.
}

\section{New Chalcone Derivatives as Effective Anti-SARS-CoV-2 Agents}

\author{
Nizami Duran ( $\nabla$ nduran@mku.edu.tr) \\ Mustafa Kemal University \\ M. Fatih Polat \\ Erzincan Binali Yildirim University \\ Derya Anil Aktas \\ Atatürk University \\ M. Abdullah Alagoz \\ Inonu University \\ Emrah Ay \\ Mustafa Kemal University \\ Funda Cimen \\ Mustafa Kemal University \\ Erhan Tek \\ Mustafa Kemal University \\ Baris Anil \\ Atatürk University \\ Serdar Burmaoglu ( $\nabla$ sboglu@atauni.edu.tr) \\ Atatürk University \\ Oztekin Algul ( $\square$ oztekinalgul@mersin.edu.tr) \\ Mersin University
}

\section{Research Article}

Keywords: Chalcone, Anti-SARS-CoV-2 activity, Viral RNA-dependent RNA polymerase, RT-PCR, Molecular docking

Posted Date: May 13th, 2021

DOI: https://doi.org/10.21203/rs.3.rs-515050/v1

License: (c) (1) This work is licensed under a Creative Commons Attribution 4.0 International License. Read Full License 


\section{Abstract}

Flavonoids and related compounds, such as quercetin-based antiviral drug Gene-Eden-VIR/Novirin, inhibit the protease of severe acute respiratory syndrome coronavirus (SARS-CoV-2). The alkylated chalcones isolated from Angelica keiskei inhibit SARS-CoV proteases. Hydroxychloroquine and Favipiravir have been used in many countries since the beginning of the pandemic with the thought that they may have antiviral activity against SARS CoV-2. In this study, we aimed to compare the anti-SARS CoV-2 activities of both newly synthesized chalcone derivatives and these two drugs. The current study aimed to determine the potent antiviral activity of newly synthesized chalcone derivatives against SARS-CoV-2 by calculating the RT-PCR cycling threshold (Ct) values. Antiviral activities of the compounds varied due to being dose dependent. Compound 6, 7, 9 and 16 were highly effective against SARS-CoV-2 at concentrations of $1.60 \mu \mathrm{g} / \mathrm{mL}$. Structure-based virtual screening was carried out against the most important druggable SARSCoV-2 targets, viral RNA-dependent RNA polymerase (RdRp), to identify putative inhibitors that could facilitate the development of potential anti-COVID19 drug candidates. Computational analyses identified eight compounds inhibiting each target, with binding affinity scores ranging from - 4,370 to $-2,748 \mathrm{kcal} / \mathrm{mol}$ along with their toxicological, $\mathrm{ADME}$, and drug-like properties.

\section{Introduction}

Coronavirus disease-2019 (COVID-19) is a highly contagious disease caused by a novel virus identified as severe acute respiratory syndrome coronavirus 2 (SARS-CoV-2). To date, there is no specific effective antiviral drug against SARS-CoV-2. The pandemic has adversely affected the global healthcare system. Treatment options for COVID-19 can be categorized into four: general treatment, coronavirus-specific treatment, antiviral treatment, and other methods. ${ }^{1,2}$ General treatment includes nutritional supplements, immune boosters, and some alternative medications in folk medicine. ${ }^{3}$ Various treatment strategies based on the use of available drugs have been tried against SARS-CoV-2 globally, but no effective treatment protocol has been found. There are many drugs, such as chlorokin/hydroxychloroquine, favipiravir, ribavirin, remdesivir or combinations of these drugs, which are found to be effective against SARS-CoV-2. ${ }^{4}$ Although some studies initially reported that one or more of these drugs were effective against SARS-CoV-2 in some countries, later some scientific studies reported that these drugs did not have the expected level of effectiveness against SARS-CoV-2.4,5

Previous treatments targeting SARS-CoV and MERS-CoV may accelerate the development of the COVID-19 treatment due to their structural and genomic similarities. Antiviral effective therapies act by arresting viral replication stages and the inactivation or inhibition of the enzymes or steps involved in these stages. One of the best characterized and conserved drug targets of coronaviruses is integrase, the main protease proteins. Inhibiting the activity of this enzyme would block viral replication, for which protease inhibitors are used. One of the most important targets that can inhibit viral replication against SARS-CoV-2 is the inactivation of the RNA-dependent RNA polymerase enzyme. Inactivation of this enzyme prevents virus replication. Today, some of the available protease and RNA polymerase enzyme inhibitor drugs are being redesigned to treat SARS-CoV-2. ${ }^{6-9}$

In cases where vaccines against SARS-CoV-2 may be insufficient, humanity's most important weapon would be an effective antiviral drug. For this reason, it is crucial to produce an effective antiviral drug against this highly contagious and deadly virus. Small modifications to the inhibitory ligand can significantly induce conformational changes in the molecules by changing the protein's binding modes and interactions to the active site and thus their activity.

In this context, some compounds that inhibit viral RNA polymerases in the literature were examined to find a scaffold, which would be active against COVID-19. The scaffold was determined to show the best activity against COVID-19. Various modifications were made to chalcone structure to design a newer, more active compound and reach the target molecules. A target molecule that could be effective against COVID-19 was designed.

Chalcone derivatives are the building blocks of pharmaceutical raw materials that have long been used to treat various diseases, and medicinal plants are structural analogs of the flavonoids they carry. Flavonoids and related compounds, such as quercetin-based antiviral drug Gene-Eden-VIR/Novirin, inhibit the protease of SARS-CoV-2. ${ }^{10}$ Chalcones also exhibit inhibitory activity against tobacco mosaic virus ${ }^{11}$, HIV ${ }^{12}$, herpes simplex virus ${ }^{13}$, and dengue virus. ${ }^{14}$ It also exhibits antioxidant ${ }^{15}$, antimicrobial ${ }^{16}$, antimycobacterial ${ }^{17}$ and antileishmanial ${ }^{18}$ properties. The alkylated chalcones isolated from Angelica keiskei inhibit SARS-CoV proteases. ${ }^{19}$

The current study aimed to determine the inhibitory activities of new eight chalcone derivatives against SARS-CoV-2 by calculating the SARS-CoV-2 RTPCR cycling threshold (Ct) values. Moreover, the toxicological, ADME and drug-like properties of the compounds were also determined by in silico method.

\section{Results}

The synthesis of the target molecules (6-9) was accomplished in one step using the Claisen-Schmidt condensation reaction, as illustrated in Fig. 1. The corresponding chalcones were obtained in high purity, and good yields by treating 2,4,6-trimethoxy benzaldehyde (1) with fluoro and trifluoromethyl substituted acetophenone derivatives (2-5) in an aqueous alkali medium. LiOH was the preferred alkaline base in the series. The reason for that nucleophilic aromatic substitution products is also obtained in reactions carried out in methanol and in a strongly basic medium, especially if the aromatic benzene ring contains fluorine. As a result of the fluorine atom's substitution by the methoxy group, methoxy chalcone structures arise as a by-product. To prevent the result from affecting the reaction efficiency, LiOH was used as an alkaline base. Tetrahydrofuran/water mixture (THF: $\mathrm{H}_{2} \mathrm{O}$ ) was determined as the reaction solvent. ${ }^{20}$ 
The synthesis of the second group of compounds (13-16) was accomplished in two steps using bromination of compound 10 followed by the Claisen-Schmidt condensation reaction, as shown in Fig. 2. By treating 2,4,6-trimethoxyacetophenone (10) with $\mathrm{LiBr}$ and ammonium cerium (IV) nitrate in $\mathrm{CH}_{3} \mathrm{CN}$, the corresponding compound 11 was obtained in high yield. Subsequently, target compounds (13-16) were obtained in high purity and good yield by the Claisen-Schmidt reaction of compound 11 with the corresponding benzaldehydes in an aqueous alkali medium (2-4, and 12).

Antiviral effects of all newly synthesized compounds against SARS-CoV-2 were assessed comparatively with standard drugs, such as favipiravir and hydroxychloroquine. The highest non-toxic concentrations of standard drugs and the compounds on Vero cells were selected for antiviral efficacy studies. The antiviral effects of three different concentrations of chalcone derivatives have been investigated.

In the study, viral growth in the Vero E6 cell line was detected by cytopathological effects (CPE) in the cells from the fourth day of incubation, as shown in Fig. 3. Activity studies in cell culture were performed after 96 hours of incubation. The characteristic CPE of SARS-CoV-2 was not detected in cell cultures in which viral reproduction was inhibited. Morphological analysis was performed by recording the CPE rate in the cells, especially the presence/absence of $\mathrm{CPE}$.

The "Ct" values give a relative measure of the viral copy number in the sample compared to the curves using the standards. Different known quantities of standards were included in the same study and tested in parallel with viral cultures. Therefore, the "Ct" value was evaluated as the potential viral (SARS-CoV-2) copy number. In this study, the inhibitory activities of new chalcone derivatives against SARS-CoV-2 were determined by calculating the SARS-CoV-2 RT-PCR "Ct" values. ${ }^{21,22}$

It has been reported that low Ct values (high viral load) can be considered an indicator of severe disease and high contagiousness. In contrast, high Ct values (low viral load) indicate a decrease in both the risk of infection and contagiousness. ${ }^{23}$

As shown in Fig. 4, the effectiveness of compounds 6-9, 14, and 16 on SARS-CoV-2 at three different concentrations (0.40, 0.80, and $1.60 \mu \mathrm{g} / \mathrm{mL})$ was compared with that of the standard drugs and the virus control group in terms of "Ct" values. When the effectiveness of standard drugs was compared with the virus control group (no drugs or chemicals included), no significantly high antiviral activities were found. It appears that there is no mention of the antiviral activity of both favipiravir and hydroxychloroquine.

The antiviral activities of compounds $\mathbf{6 - 9}, \mathbf{1 4}$, and 16 at high concentrations (1.6 and $0.8 \mu \mathrm{g} / \mathrm{mL})$ were statistically significantly higher when compared to the virus control group and the standard drugs. No statistically significant differences were found when the antiviral activity of compound $\mathbf{8}$ at a concentration of $0.4 \mu \mathrm{g} / \mathrm{mL}$ was compared with the standard drugs and virus control group. The antiviral efficacy of compound 8 was lower than that of the compounds.

There was also a dose-dependent change in the antiviral efficacy of the compounds. While the highest efficacy was determined at a concentration of $1.60 \mu \mathrm{g} / \mathrm{mL}$, it was evinced that antiviral activity decreased at a concentration of 0.8 and $0.4 \mu \mathrm{g} / \mathrm{mL}$. Comparing the antiviral activities of the compounds at different concentrations; Compound $6>7>16>9>14>8$ at $1.60 \mu \mathrm{g} / \mathrm{mL}$; compound $7>6>9>16>14>8$ at $0.80 \mu \mathrm{g} / \mathrm{mL} ; 7>6=9>16=$ $14>\mathbf{8}$ at $0.40 \mu \mathrm{g} / \mathrm{mL}$ ranking has been determined. After evaluating the results, it was found that the antiviral activities of $6,7,9$ and 16 of the first group compounds were remarkable. Hence it was noted that compounds $6,7,9,14$, and 16 exhibited statistically significantly higher antiviral activities than compound $\mathbf{8}$ against SARS-CoV-2 at all concentrations.

The antiviral effects of the second group of compounds (13 and 15) at three different concentrations $(2.0,1.0,0.5 \mu \mathrm{g} / \mathrm{mL}) \mathrm{have} \mathrm{been} \mathrm{examined.} \mathrm{As}$ shown in Fig. 5, there was no significant difference between the 2.0 and $1.0 \mu \mathrm{g} / \mathrm{mL}$ concentrations of compound 13 against SARS-CoV-2. Compound 13 was found to exhibit a dose-dependent antiviral activity. However, at a concentration of $0.5 \mu \mathrm{g} / \mathrm{mL}$, antiviral efficacy was not different from standard drugs and the virus control group. While the antiviral activity of compound $\mathbf{1 3}$ at a concentration of $1 \mu \mathrm{g} / \mathrm{mL}$ was not different from that of favipiravir, it was found to be statistically significantly higher than the effectiveness of hydroxychloroquine in $2 \mu \mathrm{g} / \mathrm{mL}$. Also, the antiviral efficacy of compound $\mathbf{1 5}$ was statistically significantly higher than the effectiveness of standard drugs at all three tested concentrations. It was determined that the antiviral efficacy of compound $\mathbf{1 5}$ at a concentration of $2 \mu \mathrm{g} / \mathrm{mL}$ against SARS-CoV-2 was not significantly different from that of a concentration of $1 \mu \mathrm{g} / \mathrm{mL}$. It was also noted that the compound exhibited a dose-dependent antiviral activity like other compounds.

In this study, eight new chalcone derivative compounds, expected to be effective against SARS-CoV2, have been synthesized. Molecular docking studies examine the binding of these compounds to target proteins and their interactions with essential residues in the proteins' active regions at the atomic level. Also, the structure-activity relationships (SAR) in this group of compounds were analyzed by comparing docking scores with in vitro results, as shown in Table 1. 
Table 1

Docking scores in $\mathrm{kcal} / \mathrm{mol}$ for molecules in target

proteins.

\begin{tabular}{|llll|}
\hline Compound & $6 \mathrm{M} 71$ & $6 \mathrm{YB} 7$ & $6 \mathrm{LGZ}$ \\
\hline 6 & $-4,370$ & $-3,953$ & $-4,127$ \\
\hline $\mathbf{8}$ & $-3,921$ & $-3,674$ & $-3,543$ \\
\hline $\mathbf{9}$ & $-3,328$ & $-3,555$ & $-3,876$ \\
\hline 13 & $-3,855$ & $-3,427$ & $-3,467$ \\
\hline 14 & $-3,266$ & $-2,748$ & $-2,974$ \\
\hline 15 & $-3,462$ & $-2,810$ & $-2,772$ \\
\hline 16 & $-3,342$ & $-2,773$ & $-3,666$ \\
\hline Favipiravir & $-3,768$ & $-3,370$ & $-3,405$ \\
\hline Hydroxychloroquine & $-2,215$ & $-2,048$ & $-2,198$ \\
\hline
\end{tabular}

The primary targets of drugs developed against SARS-CoV2 are specified as $\mathrm{M}^{\text {pro, }}, \mathrm{RdRp}$, and spike proteins in the literature. In silico studies have investigated the SARS-CoV2 inhibition potential of newly synthesized compounds using the target proteins. ${ }^{28}$ In this context, $6 \mathrm{M} 71$ PDB encoded protein (SARS-CoV-2 RNA-dependent RNA polymerase in complex with cofactors) was used for RNA-dependent RNA polymerase, 6YB7 PDB encoded protein (SARS-CoV-2 main protease with unliganded active sites) for $\mathrm{M}^{\mathrm{p} r o}$, and 6LZG PDB encoded protein (Structure of novel coronavirus spike receptor-binding domain complexed with its receptor ACE2) was used for spike protein. The interactions of synthesized compounds and reference molecules with target proteins are given in Table 2. 
Table 2

Interactions of compounds with active sites of the target proteins.

\begin{tabular}{|c|c|c|c|c|}
\hline Entry & $\begin{array}{l}\text { Interactions } \\
\text { Type }\end{array}$ & $6 \mathrm{M} 71$ & 6YB7 & 6LGZ \\
\hline \multirow[t]{8}{*}{6} & H-bound & Ser814 & Lys5 & Arg403, Gly496 \\
\hline & \multirow[t]{3}{*}{ Hydrophobic } & Ala762, Leu758, & \multirow[t]{3}{*}{ Leu286,Tyr126 } & $\begin{array}{l}\text { Tyr495, Tyr505, Phe497, Tyr453, Ala387, } \\
\text { Pro389, }\end{array}$ \\
\hline & & Cys813, Cys799, & & Phe390 \\
\hline & & Trp800, Trp617, Tyr619 & & \\
\hline & \multirow[t]{2}{*}{ Charged $(-)$} & Asp618, Asp761, & Glu288, Asp289, & Asp38, Glu37, Glu35, Glu406 \\
\hline & & Asp760, Glu811 & Glu290, Asp197 & \\
\hline & Charged (+) & Lys798 & Arg131, Lys137, & Lys353,Arg393 \\
\hline & Polar & & Ser139,Gln127 & Ser494, Gln493, His34, Asn33, GIn389 \\
\hline \multirow[t]{7}{*}{7} & H-bound & Ser814 & Lys5 & Arg403 \\
\hline & Hydrophobic & $\begin{array}{l}\text { Ala762, Cys813, Cys622, } \\
\text { Tyr619, }\end{array}$ & Leu286, Cys128, & $\begin{array}{l}\text { Tyr495, Tyr505, Phe497, Tyr453, Ala387, } \\
\text { Pro389, Phe390 }\end{array}$ \\
\hline & & Trp800, Trp617, Tyr619 & & \\
\hline & Charged $(-)$ & Asp618, Asp761, & Glu288,Asp289, & Asp38, Glu37, \\
\hline & & Asp760, Glu811 & Glu290,Asp197 & Glu35, Glu406 \\
\hline & Charged (+) & Lys798 & Arg131,Lys137, & Arg393 \\
\hline & Polar & His810 & Ser284 & Ser494, Gln493, His34, Asn33, Gln389 \\
\hline \multirow[t]{9}{*}{8} & \multicolumn{4}{|l|}{ H-bound } \\
\hline & \multirow[t]{4}{*}{ Hydrophobic } & Ala762, Phe812, & Leu286, Leu287, & \multirow[t]{4}{*}{ Tyr505, Ala387, Ala386, Phe356,Val503 } \\
\hline & & Cys813, Pro620 & Cys128 & \\
\hline & & Trp800, Trp617, & & \\
\hline & & Tyr619, Val763 & & \\
\hline & Charged $(-)$ & Asp618, Asp761, & Glu288, Asp289, Glu290 & Asp405 \\
\hline & & Asp760,Glu811 & & \\
\hline & Charged (+) & Lys798, Lys621 & Lys137,Lys5 & Arg403,Arg393 \\
\hline & Polar & & Gln127,Ser284,Thr199 & His34,Thr324 \\
\hline \multirow[t]{11}{*}{9} & \multicolumn{4}{|l|}{ H-bound } \\
\hline & \multirow[t]{5}{*}{ Hydrophobic } & Ala762, Leu758, & Leu286,Tyr126, & Tyr505,Ala387,Ala387, \\
\hline & & Cys813, Phe812 & Leu287,Tyr237, & Tyr453 \\
\hline & & Trp800,Trp617, & \multirow[t]{3}{*}{ Tyr239 } & \\
\hline & & Tyr619,Val763 & & \\
\hline & & Cys622, Pro620 & & \\
\hline & \multirow[t]{2}{*}{ Charged $(-)$} & Asp618, Asp761, & \multirow{2}{*}{$\begin{array}{l}\text { Glu288, Asp289, Glu290, } \\
\text { Asp197 }\end{array}$} & \multirow[t]{2}{*}{ Glu37, Glu35, Glu406 } \\
\hline & & Asp760, Glu811 & & \\
\hline & \multirow[t]{2}{*}{ Charged (+) } & \multirow[t]{2}{*}{ Lys798, Lys621 } & Arg131, Lys137, & Arg403, Arg408, Lys353, \\
\hline & & & Lys5 & Lys417 \\
\hline & Polar & & Asn238,Thr199,Thr198 & His34 \\
\hline 13 & H-bound & Trp800 & & \\
\hline
\end{tabular}




\begin{tabular}{|c|c|c|c|c|}
\hline Entry & $\begin{array}{l}\text { Interactions } \\
\text { Type }\end{array}$ & $6 \mathrm{M} 71$ & 6YB7 & $6 \mathrm{LGZ}$ \\
\hline & Hydrophobic & Cys813, Cys799, & Leu286, Leu287, Tyr239 & Tyr505, Ala387, Tyr453, \\
\hline & & Phe812,Trp800, & & Tyr495 \\
\hline & & Trp617, Ala797 & & \\
\hline & Charged (-) & Asp618, Asp761, & Glu288, Asp289, & Glu37, Asp38, Glu406, \\
\hline & & Glu811 & Glu290, & Asp405 \\
\hline & Charged (+) & Lys798 & Arg131, Lys137, & Arg403, Lys353, Lys414 \\
\hline & Polar & Ser814,His810 & Ser284,Thr199 & His34,Gln409 \\
\hline \multirow[t]{8}{*}{14} & H-bound & & & \\
\hline & Hydrophobic & Cys799, Tyr619, & Leu286, Leu287, & Tyr505, Ala387, Tyr453, \\
\hline & & Phe812, Trp800, & Tyr239 & Tyr495 \\
\hline & & Trp617, Ala797 & & \\
\hline & Charged (-) & Asp618,Asp761, & Glu288,Asp289,Glu290, & Glu37, Asp38, Glu406, \\
\hline & & Glu796,Glu811 & & Asp405 \\
\hline & Charged (+) & Lys798 & Arg131,Lys137, & Arg403, Arg393, Lys417 \\
\hline & Polar & & Ser284,Thr199 & His34, Asn33, Ser494 \\
\hline \multirow[t]{7}{*}{16} & $\mathrm{H}$-bound & Ser814 & Asp289 & Gly496, Arg403 \\
\hline & Hydrophobic & Leu758, Phe812, & Leu286, Leu287, Thr126, & Tyr505, Ala387, Tyr453, \\
\hline & & $\begin{array}{l}\text { Cys813, Trp800, Trp617, } \\
\text { Tyr619 }\end{array}$ & & Tyr495 \\
\hline & Charged (-) & Asp618, Asp761, & Glu288, Glu290, & Glu37, Asp38, Glu406, \\
\hline & & Asp760, Glu811 & & \\
\hline & Charged (+) & Lys798 & Arg131, Lys137, Lys5 & Arg403, Lys353, Arg393 \\
\hline & Polar & & Ser139,GIn127 & His34, Asn33, Ser494 \\
\hline \multirow[t]{9}{*}{15} & H-bound & Ser814 & Lys5 & Arg403 \\
\hline & Hydrophobic & Cys813, Cys799, & $\begin{array}{l}\text { Leu286, Leu287, Ala285, } \\
\text { Leu282 }\end{array}$ & Tyr505, Ala387, Ala386, Phe356 \\
\hline & & Trp800, Phe812, & & \\
\hline & & Ala797 & & \\
\hline & Charged (-) & Asp618, Asp761, & Glu288, Asp289, Glu290, & Glu37, Asp405, Glu406, \\
\hline & & Glu811 & & \\
\hline & Charged (+) & Lys798 & Lys137, Arg131 & Arg403, Lys353, Arg393, \\
\hline & & & & Arg408, Lys417 \\
\hline & Polar & His810 & Thr199 & His34, Gln409 \\
\hline \multirow[t]{6}{*}{ Favipiravir } & H-bound & Lys621 & Asp197 & \\
\hline & Hydrophobic & Pro620 & Leu286, Leu287 & Tyr505, Tyr495, Tyr453, Phe497 \\
\hline & Charged (-) & Asp618, & Glu288, Asp289, & Glu37, Glu37, Asp38 \\
\hline & Charged (+) & Lys798, Lys551, & Lys137, Arg131 & Arg403, Lys353 \\
\hline & & Arg553, Lys621 & & \\
\hline & Polar & & Thr199, Thr198 & His34, Gln493, Ser494 \\
\hline Hydroxychloroquine & H-bound & & & \\
\hline
\end{tabular}




\begin{tabular}{|lllll|}
\hline Entry & $\begin{array}{l}\text { Interactions } \\
\text { Type }\end{array}$ & 6M71 & 6YB7 & 6LGZ \\
\hline Hydrophobic & $\begin{array}{l}\text { Trp800, Phe812, } \\
\text { Ala797, Trp617, } \\
\text { Ala762, Tyr619 }\end{array}$ & $\begin{array}{l}\text { Leu286, Leu287, } \\
\text { Leu272, Leu287 }\end{array}$ & $\begin{array}{l}\text { Tyr505, Tyr495, Tyr453, Phe497, Phe390, } \\
\text { Ala387 }\end{array}$ \\
& Asp618, Asp761, & Glu288, Asp289, Glu290 & Asp38, Glu37, Glu406 \\
\hline Charged (-) & Glu811, Asp618 & Lys137, Arg131, & Arg403, Arg393, Lys353 \\
& Lys798 & Lys5 & His34, Asn33, Gln493, \\
\hline Charged (+) & Polar & His810 & Ser494 \\
\hline
\end{tabular}

The replication mechanism of SARS-CoV-2 is mainly governed by RNA-dependent RNA polymerase (RdRp), the nsps 12,8 , and 7 complexes. ${ }^{29}$ This 6M71 PDB encoded RdRp protein is mainly extracted from SARS-CoV2. ${ }^{30}$ It has been reported that Ser759, Asp760, Asp761, Asp618, residues located in the catalytic region of the protein, are required for replication. ${ }^{30,31}$ The docking scores of the compounds varied between $-4,340$ and $-3,266$ $\mathrm{kcal} / \mathrm{mol}$. The docking scores of favipiravir and hydroxychloroquine were $-2,658$ and $-2,215 \mathrm{kcal} / \mathrm{mol}$, respectively. As a result of docking studies, compound 6 made a hydrogen bond with Ser814; a charged (negative) interaction with Asp760, Asp761, Asp618, and its binding affinity was determined at $-4,370 \mathrm{kcal} / \mathrm{mol}$, as shown in Fig. 6.

Viral RNAs were converted into various polyproteins with the effect of $\mathrm{M}^{\text {pro }}$ of SARS-CoV2. Moreover, 6YB7 PDB encoded protein was used as a target protein in docking studies. The docking scores of the compounds ranged from - 3,953 to $-2,748 \mathrm{kcal} / \mathrm{mol}$, whereas the docking scores of favipiravir and hydroxychloroquine were - 2,271 and - 2,048 kcal/mol, respectively. It has been reported that Lys5, Ala285, Leu286, Glu288, Asp289, Glu290, located in the catalytic region of the protein, were responsible for the disruption of $\mathrm{M}^{\text {pro }}{ }^{28}$ Compound $\mathbf{6}$ with the highest activity and docking score of $-3,953 \mathrm{kcal} / \mathrm{mol}$ made hydrogen bond with Lys5; hydrophobic interaction with Leu286; and a charged (negative) interaction with lu288, Asp289, Glu290, as shown in Fig. 7.

The spike (S) protein, one of the target proteins for SARS-CoV2, gives the virus its typical shape, contains a specific binding site that allows it to attach to the host cell. It attacks angiotensin-converting enzyme 2 (ACE-2) receptors in the host cell. 6LZG PDB encoded protein was used as the target protein. The residues in the protein's catalytic region have been reported as Arg403, Tyr453, Gly496, Gln498, Asn501, Gly502, Tyr503, Tyr505. The docking scores of the compounds ranged from -4.127 to $-2.772 \mathrm{kcal} / \mathrm{mol}$. The docking scores of favipiravir and hydroxychloroquine were -2.555 and $-2.198 \mathrm{kcal} / \mathrm{mol}$, respectively. In addition to having a high docking score of $-4.127 \mathrm{kcal} / \mathrm{mol}$, compound 6 made a hydrogen bond with Arg 403 and Gly496, as shown in Fig. 6.

Docking studies conducted for different target proteins are in harmony with biological activity studies. All of the synthesized compounds are found to be more active than favipiravir and hydroxychloroquine. Compound $\mathbf{6}$ (Ct value: 32 ), the compound with the best activity against SARS-CoV2, also has the highest docking scores in all target proteins. The Ct values of favipiravir and hydroxychloroquine are calculated as $\mathbf{1 8}$ and $\mathbf{1 4}$, respectively. Although the most active compound concentration of compound 6 on which it is effective is $4.78 \mu \mathrm{M}$, favipiravir and hydroxychloroquine are effective at $95.47,59.54 \mu \mathrm{M}$, respectively. These results show that the efficacy of compound 6 against SARS-CoV2 is higher than that of favipiravir and hydroxychloroquine. Molecular docking studies support these activity results.

Besides bioactivity studies and molecular docking studies, the physicochemical and ADMET properties of the compounds are critical in terms of druglikelihood. Many compounds with significant biological activity do not make it to clinical trials due to their unsuitable physicochemical and toxicological properties. These properties of the compounds are described in QikProp (Maestro, Schrodinger 11.8), Datawarrior v4.07.02. and preADMET software (https://preadmet.bmdrc.kr). ${ }^{32}$ The compounds' toxicological evaluation shows that none of them has the potential to be carcinogenic or mutagenic. Also, the compounds exhibit medium-level ability to inhibit the hERG potassium channel and CYP450. For ADMET properties, it has been shown that the properties of all compounds are suitable. In addition, all of the synthesized compounds comply with Lipinski's rule of five. Details of the physicochemical and ADMET properties of the compounds are given in Table 3 and Table 4, respectively. 
Table 3

Physicochemical properties.

\begin{tabular}{|c|c|c|c|c|c|c|c|c|c|c|c|}
\hline Comp. & $\begin{array}{l}\mathrm{mol} \\
\mathrm{MW}\end{array}$ & SASA & FOSA & FISA & PISA & WPSA & Mol Vol & donorHB & accptHB & $\log P$ & PSA \\
\hline 7 & 334,319 & 611,988 & 278,05 & 44,731 & 196,544 & 92,663 & 1052,629 & 0 & 4,25 & 4,347 & 46,299 \\
\hline 6 & 334,319 & 618,356 & 290,337 & 39,884 & 203,367 & 84,769 & 1054,929 & 0 & 4,25 & 4,368 & 46,378 \\
\hline 8 & 384,327 & 660,507 & 290,005 & 39,861 & 175,101 & 155,54 & 1136,17 & 0 & 4,25 & 4,042 & 46,338 \\
\hline 9 & 434,334 & 674,253 & 274,353 & 45,126 & 132,87 & 221,904 & 1197,133 & 0 & 4,25 & 4,790 & 47,399 \\
\hline 13 & 399,188 & 605,368 & 189,772 & 63,966 & 198,165 & 153,465 & 1037,028 & 0 & 3,25 & 3,744 & 55,99 \\
\hline 14 & 399,188 & 607,615 & 193,461 & 64,012 & 187,997 & 162,145 & 1039,649 & 0 & 3,25 & 3,744 & 55,999 \\
\hline 16 & 417,179 & 613,568 & 189,77 & 63,966 & 164,586 & 195,246 & 1052,298 & 0 & 3,25 & 3,845 & 55,989 \\
\hline 15 & 449,196 & 651,589 & 201,216 & 65,711 & 159,479 & 225,183 & 1123,502 & 0 & 3,25 & 4,492 & 57,717 \\
\hline Favipravir & 157,104 & 317,525 & 0 & 204,356 & 64,025 & 49,145 & 477,264 & 1 & 4 & $-1,796$ & 105,118 \\
\hline Hydroxychloroquine & 335,876 & 666,073 & 338,473 & 68,462 & 187,662 & 71,475 & 1164,305 & 2 & 5,7 & 3,082 & 48,021 \\
\hline \multicolumn{12}{|c|}{ Determined by QikProp (Maestro, Schrodinger 11.8) } \\
\hline \multicolumn{12}{|c|}{$\begin{array}{l}\text { mol MW: molecular weight of molecule. SASA: total solvent accessible surface area in square angstroms using a probe with a } 1.4 \AA \AA \text { a radius. FOSA: } \\
\text { hydrophobic component of SASA. FISA: hydrophilic component of SASA. PISA: Pi (carbon and attached hydrogen) component of SASA. WPSA: } \\
\text { weakly polar component of the SASA (halogen, P and S). Total solvent-accessible volume in cubic angstroms using a probe with a } 1.4 \AA \text { Aadius Mol } \\
\text { Vol: Total solvent-accessible volume in cubic angstroms using a probe with a } 1.4 \text { A radius. Donor HB: Estimated number of hydrogen bonds that } \\
\text { would be donated by the solute to water molecule in an aqueous solution. accpt HB: Estimated number of hydrogen bonds that would be accepted } \\
\text { by the solute from water molecule in an aqueous solution. LogP: Predicted octanol/water partition coefficient.PSA: polar surface area. }\end{array}$} \\
\hline
\end{tabular}

\begin{tabular}{|c|c|c|c|c|c|c|c|c|c|c|}
\hline Premeners & ? & $\cdot$ & 1 & , & D & 14 & 16 & 15 & Tmipromit & 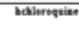 \\
\hline \multicolumn{11}{|l|}{ 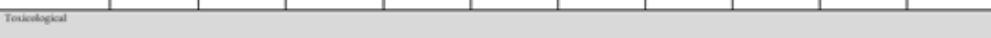 } \\
\hline 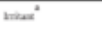 & $x$ & Nox & Now & $x=$ & Nos & Nose & Noos & Nox & sex & $\sin$ \\
\hline $\cos ^{2}$ & $x=$ & Now & Now & $x=$ & som & $\sin$ & $\operatorname{sen}$ & Now & sex & $x \rightarrow \infty$ \\
\hline 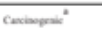 & vox & $\operatorname{sen}$ & sen & $x=$ & $x=$ & som & Now & Seer & sie & $N=$ \\
\hline Mespent" & von & Non & so & $x=$ & $n$ & 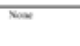 & Non & Nom & 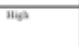 & $x \in$ \\
\hline 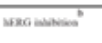 & 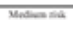 & 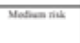 & 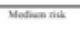 & vosemina & 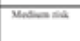 & 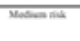 & 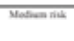 & 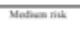 & Yvaseraid & 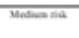 \\
\hline 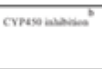 & 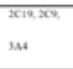 & 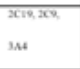 & 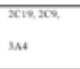 & 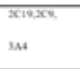 & 3c12.80, & 3c19.8Q & XC18.250 & 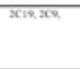 & 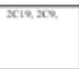 & $\overline{3196}$ \\
\hline \multicolumn{11}{|l|}{ ADQu } \\
\hline 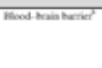 & Len & Les & wase & 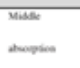 & 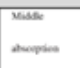 & 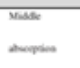 & 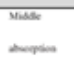 & mese & 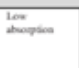 & men \\
\hline 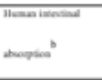 & sated & tata & sallased & Fala & sala & sald & Wall & tontiod & 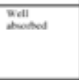 & 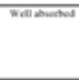 \\
\hline 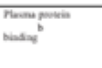 & $=0$ & $=$ & sind & sont & $=$ & $=$ & $=0$ & $=$ & 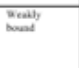 & 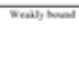 \\
\hline$c^{n}=a^{\circ}$ & Pasese & mases & miseses & pases & sasese & Nascos & mases & miseces & 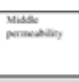 & Nasces \\
\hline \multicolumn{11}{|l|}{ मिक्य } \\
\hline$=$ & 4,488 & this & s'seos & . & 2391 & 290 & 290 & Stso & 286 & \\
\hline 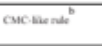 & ontind & ontated & attited & onthed & ondind & entions & ond & ow thend & 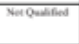 & onstined \\
\hline 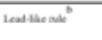 & velemed & voleded & voleded & voled & valesed & voleded & voled & volied & seache & vesend \\
\hline Sheterfan' & sean & $\operatorname{sen}$ & seden & $\operatorname{sen}$ & $\operatorname{sedn}$ & $\operatorname{sen}$ & $\operatorname{sen}$ & $\sin$ & seans & seath \\
\hline 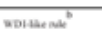 & $\operatorname{sedn}$ & $\operatorname{sen}$ & $\operatorname{sen}$ & ost & sesth & $\operatorname{seds}$ & $\operatorname{sen}$ & 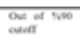 & $\operatorname{sen} 20$ & sesale \\
\hline
\end{tabular}

2Determined by datawarrior v4.07.02. 'betermined by pre-admet (https $/ /$ /preadmet.bmdrc.kr).

\section{Discussion}

COVID-19 is a highly contagious viral disease caused by coronavirus SARS-CoV-2, belonging to the beta coronavirus family. Currently, there is no effective specific antiviral treatment option for SARS-CoV-2. However, several studies for using existing antivirals in isolation or combination and developing new therapeutic drugs to treat COVID-19 are underway. More extensive studies are needed to determine the reliability and effectiveness of these new drug candidates and to guide clinical decisions. Today, COVID-19 is a global health problem worldwide and is a serious and potential threat to human health. It is crucial to develop new protection strategies against SARS-CoV-2 and discover new active molecules against this virus. Studies are conducted on different structures; among them, one is chalcone scaffold. Chalcones are bioactive scaffolds of great medicinal interest due to their 
various pharmacological and biological activities to provide a valuable scaffold for discovering new drug leads. The current study aimed to determine the inhibitory activities of new chalcone derivatives against SARS-CoV-2 by calculating the "Ct" values of SARS-CoV-2 by RT-PCR method.

In the study, the antiviral activities of new chalcone derivatives were evaluated by calculating their "Ct" values compared to that of the standard drugs and virus control group. In addition, the morphological appearance of the cells in each group and the viability rates of the collected cells were also evaluated. Morphological evaluation by microscopy and cell viability can also be considered a verification of "Ct" values. In cultures with a low "Ct" value (high viral load), intense CPE was detected in cells, and low cell viability was interpreted as an indicator of high viral reproduction. In cultures with a high "Ct" value (low viral load), the absence of CPE or the presence of minimal CPE in cells and high cell viability rates were interpreted as a low viral titer. Finally, in the experiments, it was indicated that compound $\mathbf{1 5}$ and all other compounds, especially the compounds $\mathbf{6}, \mathbf{7}$, and $\mathbf{9}$ showed remarkable antiviral activity against SARS-CoV-2.

Unfortunately, currently, there is no effective drug against SARS-CoV-2. For most people, the disease may cause mild illness; however, it can cause severe morbidity and even mortality in some people. Although there is no clear explanation for this situation, it is reported to be closely associated with host immunity.

The present study found that the newly synthesized chalcone derivatives showed a significant level of antiviral activity. The results indicated that the antiviral activities of the synthesized compounds were dose-dependent. Also, Compound $\mathbf{6 , 1 5}$, and 16 have been found to possess potent activity against SARS-CoV-2 at the concentrations of $1.60,2.0$, and $1.60 \mu \mathrm{g} / \mathrm{mL}$, respectively.

Chalcone derivatives were also analyzed in silico for their pharmacokinetic properties and were validated as having drug-like nature. This library was considered for tackling the modern-day issue of SARS-CoV-2 and further tested against homology modeled M ${ }^{\text {pro }}$, RdRp, and S proteins. Considering the potential efficacy of these newly synthesized compounds against SARS-CoV-2, we believe that these molecules may be potentially effective drug candidates. However, further studies are needed to test the effectiveness of these molecules by in-vivo tests.

\section{Materials And Methods Chemistry experimental procedure}

General. All reagents used were commercially available unless otherwise specified and all solvents were distilled before use. Melting points were measured with Gallenkamp melting point devices. IR Spectra: PerkinElmer Spectrum One FT-IR spectrometer. ${ }^{1} \mathrm{H}$ - and ${ }^{13} \mathrm{C}$-NMR Spectra: Varian 400 and Bruker 400 spectrometers. Elemental analysis results were obtained on a Leco CHNS-932 instrument.

\section{General Procedure for Preparation of Compounds (6-9)}

To a solution of flouro/triflouro substituted acetophenone derivatives (2-5) (1 mmol), in THF: $\mathrm{H}_{2} \mathrm{O}(5: 1,10$ mL) 2,4,6-trimethoxybenzaldehyde (1) (1,5 $\mathrm{mmol})$ and $\mathrm{LiOH} . \mathrm{H}_{2} \mathrm{O}(10 \mathrm{mmol})$ were added and resultant mixture was sequentially stirred overnight at room temperature. The solvent was evaporated in vacuum. $2 \mathrm{M} \mathrm{HCl}$ solution $(5 \mathrm{~mL})$ was added and crude material was extracted with ethyl acetate (EtOAc) (25 mL x 3). The combined extracts were dried over $\mathrm{Na}_{2} \mathrm{SO}_{4}$. The solvent was removed in vacuum and the remaining residue purified via column chromatography over silicagel using gradient elution with EtOAc and hexanes to yield compound 6-9.

\section{(E )-1-(2,5-difluorophenyl)-3-(2,4,6-trimethoxyphenyl)prop-2-en-1-one (6)}

The above procedure was followed with 2,5-difluoroacetophenone (2) to yield 6 as a yellow solid $(61 \%$ yield $) . R_{f}(\mathrm{EtOAc} / \mathrm{Hexanes} 20: 80)=0.46$; $\mathrm{mp}=$

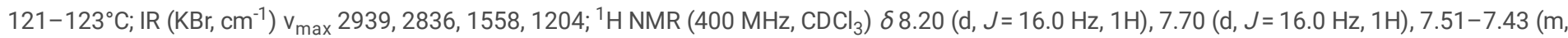
$1 \mathrm{H}), 7.19-7.04(\mathrm{~m}, 2 \mathrm{H}), 6.11(\mathrm{~s}, 2 \mathrm{H}), 3.88(\mathrm{~s}, 6 \mathrm{H}), 3.85(\mathrm{~s}, 3 \mathrm{H}) ;{ }^{13} \mathrm{C} \mathrm{NMR}\left(100 \mathrm{MHz}, \mathrm{CDCl}_{3}\right) \delta 189.3,163.7,161.9,158.6\left(\mathrm{C}-5\right.$ ", $\left.\mathrm{d}, J_{C, F}=243.5 \mathrm{~Hz}\right), 156.9$ $\left(\mathrm{C}-2^{\prime \prime}, \mathrm{d}, J_{C, F}=247.2 \mathrm{~Hz}\right), 137.3,129.4\left(\mathrm{C}-1^{\prime \prime}, \mathrm{dd}, J_{C, F}=16.2,6.7 \mathrm{~Hz}\right), 124.8,119.4\left(\mathrm{C}-4 ", \mathrm{dd}, J_{C, F}=24.5,8.9 \mathrm{~Hz}\right), 117.7\left(\mathrm{C}-3^{\prime \prime}, \mathrm{dd}, J_{C, F}=26.3,7.8 \mathrm{~Hz}\right), 116.9$ $\left(C-6 "\right.$, dd, $\left.J_{C, F}=24.4,4.2 \mathrm{~Hz}\right), 106.3,90.5,55.8,55.4$; Anal. calcd for $\mathrm{C}_{18} \mathrm{H}_{16} \mathrm{~F}_{2} \mathrm{O}_{4}$ : C, 64.67; H, 4.82; Found: C, 64.71; $\mathrm{H}, 4.72$.

\section{(E )-1-(3,5-difluorophenyl)-3-(2,4,6-trimethoxyphenyl)prop-2-en-1-one (7)}

The above procedure was followed with 3,5-difluoroacetophenone $(3)$ to yield 7 as a yellow solid $(65 \%$ yield $) . R_{f}($ EtOAc/ Hexanes $20: 80)=0.5 ; \mathrm{mp}=$ 173-175 $\mathrm{C}$; IR $\left(\mathrm{KBr}, \mathrm{cm}^{-1}\right) \mathrm{v}_{\max } 3084,2942,1563,1121 ;{ }^{1} \mathrm{H}$ NMR $\left(400 \mathrm{MHz}, \mathrm{CDCl}_{3}\right) \delta 8.29(\mathrm{~d}, J=16.0 \mathrm{~Hz}, 1 \mathrm{H}), 7.75(\mathrm{~d}, J=16.0 \mathrm{~Hz}, 1 \mathrm{H}), 7.57-7.45(\mathrm{~m}$, $2 \mathrm{H}), 7.03-6.93(\mathrm{~m}, 1 \mathrm{H}), 6.14(\mathrm{~s}, 2 \mathrm{H}), 3.92(\mathrm{~s}, 6 \mathrm{H}), 3.87(\mathrm{~s}, 3 \mathrm{H}) ;{ }^{13} \mathrm{C} \mathrm{NMR}\left(100 \mathrm{MHz}, \mathrm{CDCl}_{3}\right) \delta 189.4,163.7,162.9\left(\mathrm{C}-3{ }^{\prime \prime}, \mathrm{dd}, J_{C, F}=236.1,12.0 \mathrm{~Hz}\right), 162.0$, 142.5 (C-1"), 137.6, 120.6, 111.3 (C-2", dd, $\left.J_{C, F}=18.7,6.9 \mathrm{~Hz}\right), 107.0$ (C-4"), 106.4, 90.6, 55.9, 55.4; Anal. calcd for $\mathrm{C}_{18} \mathrm{H}_{16} \mathrm{~F}_{2} \mathrm{O}_{4}$ : C, $64.67 ; \mathrm{H}_{\text {, } 4.82 ;}$ Found: C, $64.79 ; \mathrm{H}, 4.75$.

\section{(E )-1-(2-fluoro-5-(trifluoromethyl)phenyl)-3-(2,4,6-trimethoxyphenyl)prop-2-en-1-one (8)}

The above procedure was followed with 2-fluoro-5-trifluoromethylacetophenone $(\mathbf{4})$ to yield $\mathbf{8}$ as a yellow solid $\left(70 \%\right.$ yield). $R_{f}($ EtOAc/Hexanes $20: 80)=$ $0.5 ; \mathrm{mp}=143-145^{\circ} \mathrm{C} ; \mathrm{IR}\left(\mathrm{KBr}, \mathrm{cm}^{-1}\right) \mathrm{v}_{\max } 2945,2313,1566,1333 ;{ }^{1} \mathrm{H} \mathrm{NMR}\left(400 \mathrm{MHz}, \mathrm{CDCl}_{3}\right) \delta 8.22(\mathrm{~d}, J=15.6 \mathrm{~Hz}, 1 \mathrm{H}), 8.11-8.04(\mathrm{~m}, 1 \mathrm{H}), 7.79-7.65$ 
$(\mathrm{m}, 2 \mathrm{H}), 7.32-7.23(\mathrm{~m}, 1 \mathrm{H}), 6.14(\mathrm{~s}, 2 \mathrm{H}), 3.91(\mathrm{~s}, 6 \mathrm{H}), 3.89(\mathrm{~s}, 3 \mathrm{H}) ;{ }^{13} \mathrm{C} \mathrm{NMR}\left(100 \mathrm{MHz}, \mathrm{CDCl}_{3}\right) \delta 189.4,163.8,162.0,159.7\left(\mathrm{C}-2{ }^{\prime \prime}, J_{C, F}=304.7 \mathrm{~Hz}\right), 137.8$,

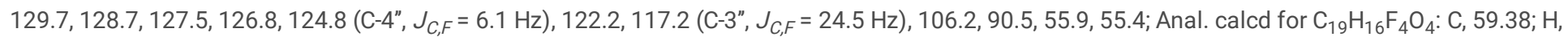
4.20; Found: C, 59.49; H, 4.22 .

\section{(E )-1-(3,5-bis(trifluoromethyl)phenyl)-3-(2,4,6-trimethoxyphenyl)prop-2-en-1-one (9)}

The above procedure was followed with 3,5-bistrifluoromethylacetophenone (5) to yield 9 as a yellow solid $(73 \%$ yield $) . R_{f}($ EtOAc/Hexanes $20: 80)=0.6$; $\mathrm{mp}=193-195^{\circ} \mathrm{C}$; IR $\left(\mathrm{KBr}, \mathrm{cm}^{-1}\right) \mathrm{v}_{\max } 2994,2302,1561,1278 ;{ }^{1} \mathrm{H} \mathrm{NMR}\left(400 \mathrm{MHz}, \mathrm{CDCl}_{3}\right) \delta 8.43(\mathrm{bs}, 2 \mathrm{H}), 8.34(\mathrm{~d}, \mathrm{~J}=15.6 \mathrm{~Hz}, 1 \mathrm{H}), 8.05(\mathrm{bs}, 1 \mathrm{H}), 7.83(\mathrm{~d}$, $J=15.6 \mathrm{~Hz}, 1 \mathrm{H}), 6.17$ (s, 2H), 3.95 (s, 6H), 3.90 (s, 3H); ${ }^{13} \mathrm{C} \mathrm{NMR}\left(100 \mathrm{MHz}, \mathrm{CDCl}_{3}\right) \delta 189.4,164.0,162.1,140.9,138.8,132.0,131.7,128.5,125.1,120.3$, 106.2, 90.6, 55.9, 55.5; Anal. calcd for $\mathrm{C}_{20} \mathrm{H}_{16} \mathrm{~F}_{6} \mathrm{O}_{4}$ : C, 55.31; $\mathrm{H}, 3.71$; Found: $\mathrm{C}, 55.33 ; \mathrm{H}, 3.75$.

\section{Synthesis procedure for 1-(3-bromo-2-hydroxy-4,6-dimethoxyphenyl)ethan-1-one (11)}

To a solution of ammonium cerium (IV) nitrate (1 eq.) and $\mathrm{LiBr}$ (1 eq.) in $\mathrm{CH}_{3} \mathrm{CN}$ (2.5 mL/1 mmol of substrate) was added 2-hydroxy-4,6dimethoxyacetophenone (10) (1 eq.). The mixture was stirred for $6 \mathrm{~h}$ at rt. After $6 \mathrm{~h}$ reaction was monitored by TLC and stopped with $\mathrm{H}_{2} \mathrm{O}$ ( $25 \mathrm{~mL}$ ), extracted with DCM $(3 \times 25 \mathrm{~mL})$. The combined extracts were dried over $\mathrm{Na}_{2} \mathrm{SO}_{4}$. The solvent was removed under reduced pressure to afford 1-(3bromo-2-hydroxy-4,6-dimethoxyphenyl)ethan-1-one (11) as a light pink solid (91\%). The ${ }^{1} \mathrm{H}$ NMR and ${ }^{13} \mathrm{C}$ NMR spectra are in agreement with the reported data. ${ }^{33}$

\section{General procedure for preparation of Compounds (13-16)}

To a solution of 1-(3-bromo-2-hydroxy-4,6-dimethoxyphenyl)ethan-1-one (11) (1 eq.) in $\mathrm{MeOH}(20 \mathrm{~mL} / 1.1 \mathrm{mmol}$ of substrate) benzaldehyde derivatives $(2-4$, and 12$)(1,6$ eq.) and $50 \%$ aqueous $\mathrm{KOH}$ solution $(7 \mathrm{~mL} / 1.1 \mathrm{mmol}$ of substrate) were added sequentially stirred for $15 \mathrm{~h}$ at room temperature. After $15 \mathrm{~h}$ solvent was evaporated. $\mathrm{NH}_{4} \mathrm{Cl}$ solution $(20 \mathrm{~mL} / 1.1 \mathrm{mmol}$ of substrate) was added and crude product was extracted with $\mathrm{DCM}$ ( $25 \mathrm{~mL} / 1.1$ mmol of substrate $\times 3$ ). The combined extracts were dried over $\mathrm{Na}_{2} \mathrm{SO}_{4}$. The solvent was removed in vacuum.

\section{(E )-1-(3-bromo-2-hydroxy-4,6-dimethoxyphenyl)-3-(2,5-difluorophenyl)prop-2-en-1-one (13)}

The above procedure was followed with 2,5-difluorobenzaldehyde (2) to yield 13 as a yellow solid $(61 \%$ yield $) . R_{f}($ EtOAc/Hexanes $20: 80)=0.43 ; \mathrm{mp}=$ 219-221 ${ }^{\circ} \mathrm{C}$; IR $\left(\mathrm{KBr}, \mathrm{cm}^{-1}\right) v_{\max } 3076,1631,1585,720 ;{ }^{1} \mathrm{H}$ NMR $(400 \mathrm{MHz}, \mathrm{DMSO}) \delta 13.83(\mathrm{bs}, 1 \mathrm{H}), 7.89(\mathrm{~d}, \mathrm{~J}=15.8 \mathrm{~Hz}, 1 \mathrm{H}), 7.71-7.59(\mathrm{~d}, 2 \mathrm{H}), 7.40-$ $7.27(\mathrm{~m}, 2 \mathrm{H}), 6.42(\mathrm{~s}, 1 \mathrm{H}), 4.00(\mathrm{~s}, 6 \mathrm{H}) ;{ }^{13} \mathrm{C}$ NMR $\left(100 \mathrm{MHz}, \mathrm{DMSO}, 55^{\circ} \mathrm{C}\right) \delta 192.6,162.6,161.6,161.3\left(\mathrm{C}-2^{\prime}, \mathrm{d}, J_{C, F}=259.3 \mathrm{~Hz}\right), 160.2\left(\mathrm{C}-5^{\prime}, \mathrm{d}, J_{C, F}=\right.$ $270.6 \mathrm{~Hz}), 157.7,133.8,131.5,124.5$ (C-1', dd, $\left.J_{C, F}=19.9,8.2 \mathrm{~Hz}\right), 119.1$ (C-3', dd, $\left.J_{C, F}=24.7,8.8 \mathrm{~Hz}\right), 118.3\left(\mathrm{C}-4^{\prime}, \mathrm{dd}, J_{C, F}=25.0,9.0 \mathrm{~Hz}\right), 115.9\left(\mathrm{C}-6^{\prime}, \mathrm{d}\right.$, $\left.J_{C, F}=25.0 \mathrm{~Hz}\right), 107.3,91.2,89.7,57.4,57.2$; Anal. calcd for $\mathrm{C}_{17} \mathrm{H}_{13} \mathrm{BrF}_{2} \mathrm{O}_{4}$ : C, 51.15; $\mathrm{H}, 3.28$; Found: $\mathrm{C}, 51.24 ; \mathrm{H}, 3.31$.

\section{( E )-1-(3-bromo-2-hydroxy-4,6-dimethoxyphenyl)-3-(3,5-difluorophenyl)prop-2-en-1-one (14)}

The above procedure was followed with 3,5-difluorobenzaldehyde $(3)$ to yield 14 as a yellow solid $(70 \%$ yield $) . R_{f}($ EtOAc/Hexanes $20: 80)=0.5 ; \mathrm{mp}=$ $221-223^{\circ} \mathrm{C}$; IR $\left(\mathrm{KBr}, \mathrm{cm}^{-1}\right) \mathrm{v}_{\max } 3061,1631,1585,720 ;{ }^{1} \mathrm{H}$ NMR $(400 \mathrm{MHz}, \mathrm{DMSO}) \delta 13.87$ (bs, $\left.1 \mathrm{H}\right), 7.82(\mathrm{~d}, J=15.6 \mathrm{~Hz}, 1 \mathrm{H}), 7.62(\mathrm{~d}, J=15.6 \mathrm{~Hz}, 1 \mathrm{H})$, 7.55-7.49 (m, 2H), 7.36-7.28 (m, 1H), $6.41(\mathrm{~s}, 1 \mathrm{H}), 3.98(\mathrm{~d}, 6 \mathrm{H}) ;{ }^{13} \mathrm{C}$ NMR $\left(100 \mathrm{MHz}, \mathrm{DMSO}, 55^{\circ} \mathrm{C}\right)$ $\delta 193.0,162.8,162.7,163.3\left(\mathrm{C}-3^{\prime}, \mathrm{dd}, J_{\mathrm{C} . F}=244.6\right.$,

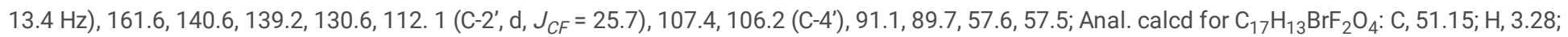
Found: $\mathrm{C}, 51.25 ; \mathrm{H}, 3.40$.

\section{(E )-1-(3-bromo-2-hydroxy-4,6-dimethoxyphenyl)-3-(2-fluoro-5-(trifluoromethyl)phenyl) prop-2-en-1-one (15)}

The above procedure was followed with 2-fluoro-5-trifluoromethylbenzaldehyde (4) to yield $\mathbf{1 5}$ as a yellow solid (45\% yield). Rf (EtOAc/Hexanes 20:80) $=0.56 ; \mathrm{mp}=206-208^{\circ} \mathrm{C}$; IR $\left(\mathrm{KBr}, \mathrm{cm}^{-1}\right) \mathrm{v}_{\max } 3332,1630,1524,726 ;{ }^{1} \mathrm{H} \mathrm{NMR}(400 \mathrm{MHz}, \mathrm{DMSO}) \delta 8.14(\mathrm{~s}, 1 \mathrm{H}), 7.91(\mathrm{~d}, J=16 \mathrm{~Hz}, 1 \mathrm{H}), 7.87-7.77(\mathrm{~m}, 1 \mathrm{H})$, $7.65(\mathrm{~d}, J=16.0 \mathrm{~Hz}, 1 \mathrm{H}), 7.59-7.47(\mathrm{~m}, 1 \mathrm{H}), 6.33(\mathrm{~s}, 1 \mathrm{H}), 3.97(\mathrm{~s}, 3 \mathrm{H}), 3.95(\mathrm{~s}, 3 \mathrm{H}) ;{ }^{13} \mathrm{C}$ NMR $\left(100 \mathrm{MHz}, \mathrm{DMSO}, 55^{\circ} \mathrm{C}\right) \delta 192.5,162.4,163.1\left(\mathrm{C}-22^{\prime}, \mathrm{d}, J_{C, F}\right.$ $=256 \mathrm{~Hz}), 162.0,161.9,132.9,132.5,129.3,128.5,127.8,126.5,124.4\left(\mathrm{C}-1^{\prime}, \mathrm{d}, J_{C, F}=12.1 \mathrm{~Hz}\right), 117.9\left(\mathrm{C}-3\right.$ ', d, $\left.J_{C, F}=23.6 \mathrm{~Hz}\right), 108.1,91.96,88.9,57.3$, 57.1; Anal. calcd for $\mathrm{C}_{18} \mathrm{H}_{13} \mathrm{BrF}_{4} \mathrm{O}_{4}$ : $\mathrm{C}, 48.13 ; \mathrm{H}, 2.92$; Found: $\mathrm{C}, 48.17 ; \mathrm{H}, 3.05$.

\section{(E )-1-(3-bromo-2-hydroxy-4,6-dimethoxyphenyl)-3-(2,4,5-trifluorophenyl)prop-2-en-1-one (16)}

The above procedure was followed with 2,4,5-trifluorobenzaldehyde (12) to yield 16 as a yellow solid $\left(60 \%\right.$ yield). $R_{f}($ EtOAc/Hexanes $20: 80)=0.46 ; \mathrm{mp}$ $=209-211^{\circ} \mathrm{C}$; IR $\left(\mathrm{KBr}, \mathrm{cm}^{-1}\right) \mathrm{v}_{\max } 3022,1638,1316,869 ;{ }^{1} \mathrm{H}$ NMR $(400 \mathrm{MHz}, \mathrm{DMSO}) \delta 13.9(\mathrm{bs}, 1 \mathrm{H}), 8.01-7.96(\mathrm{~m}, 1 \mathrm{H}), 7.86(\mathrm{~d}, \mathrm{~J}=16 \mathrm{~Hz}, 1 \mathrm{H}), 7.71-$ $7.63(\mathrm{~m}, 1 \mathrm{H}), 7.60(\mathrm{~d}, J=16 \mathrm{~Hz}, 1 \mathrm{H}), 6.40(\mathrm{~s}, 1 \mathrm{H}), 3.97(6 \mathrm{H}) ;{ }^{13} \mathrm{C}$ NMR $\left(100 \mathrm{MHz}, \mathrm{DMSO}, 55^{\circ} \mathrm{C}\right) \delta 192.7,162.7,162.8,161.9,157.2\left(\mathrm{C}-22^{\prime}, \mathrm{ddd}, J_{C, F}=\right.$ 249.0, 11.1, 2.4 Hz), 151.0 (C-5', dd, $\left.J_{C, F}=238.4,13.7 \mathrm{~Hz}\right), 147.2\left(\mathrm{C}-4^{\prime}\right.$, ddd, $\left.J_{C, F}=257.2,12.1,3.0 \mathrm{~Hz}\right), 133.4,131.1,120.3\left(\mathrm{C}-1^{\prime}\right), 117.9\left(\mathrm{C}-6^{\prime}, \mathrm{dd}^{\prime}, J_{C, F^{\prime}}=\right.$ 20.2, 3.5 Hz), 107.6 (C-3', dd, $\left.J_{C, F}=28.9,21.5 \mathrm{~Hz}\right), 107.2,91.1,89.7,57.6,57.4$; Anal. calcd for $\mathrm{C}_{17} \mathrm{H}_{12} \mathrm{BrF}_{3} \mathrm{O}_{4}$ : C, 48.94; $\mathrm{H}, 2.90 ;$ Found: C, 49.01; H, 2.95. Biological part 


\section{Viral propagation}

The SARS-CoV-2 Hatay strain (SARS-CoV-2, Hatay, 2020), isolated by Professor Dr. Nizami Duran, was used in the study. The SARS-CoV-2 strain was propagated in the Vero E6 cell line (African green monkey kidney cells), obtained from the American Type Culture Collection (ATCC C1008). After seven days of incubation at $37^{\circ} \mathrm{C}$ in an atmosphere of $5 \% \mathrm{CO}_{2}$, the supernatant was harvested.

Vero E6 cell line was used for viral isolation. Cell cultures were maintained with 10\% fetal calf serum in RPMI-1640 medium containing 10 mM HEPES, $4 \mathrm{IM}$ glutamine, and $100 \mathrm{IU} / \mathrm{ml}$ penicillin/streptomycin. Incubation of cells was carried out at $37{ }^{\circ} \mathrm{C}$ in an incubator with $95 \%$ air and $5 \% \mathrm{CO}_{2}$. Cell density was adjusted to $1 \times 10^{5}$ cells per $\mathrm{ml}$. Experiments were performed by adding cell maintenance medium to $10 \%$ of the culture dish in culture dishes. Incubation of cell cultures continued for 96 hours. Cells were removed from the culture vessels with $0.25 \%$ trypsinization solution and collected in $50 \mathrm{ml}$ centrifuge tubes by centrifugation at $1250 \mathrm{rpm}$ for 10 minutes at the end of incubation. Cell number and viability were determined by hemocytometer with $1 \%$ trypan blue dye prepared in $0.9 \% \mathrm{NaCl}$.

Viral growth was confirmed both by determining the presence of cytopathological effect and by the Real-Time PCR method. The formation of CPE was detected on the 4th day in the Vero cell line.

\section{Proliferation Experiments}

DMSO was used to dissolve the chemical compounds at a concentration nontoxic to Vero cells. Proliferation experiments in cell culture were performed on 24-well flat-bottom microplates. The wells were prepared with RPMI-1640 medium containing $10 \%$ fetal calf serum at a density of $1 \times 10^{5}$ cells per $\mathrm{ml}$.

\section{Titration of the Virus}

Stock viral strains (maintained at $-80^{\circ} \mathrm{C}$ ) were rapidly dissolved in $37^{\circ} \mathrm{C}$ water (in a bain-marie) and were re-activated in cell lines (Vero E6 cell line). The cells were then exploded by "freezing and thawing". Cells were collected from the culture dish and centrifuged at $4000 \mathrm{rpm}$ for 20 minutes, and the supernatant virus was collected as a stock solution. Like in our previous study in which $\mathrm{TCID}_{50}$ of the virus was calculated ${ }^{34}$; in the present study, three different titers of SARS-CoV-2 $\left(1,10\right.$, and 100 TCID $\left._{50}\right)$ were chosen to be studied.

\section{Activity Studies}

\section{3- (4,5-Dimethylthiazol-2-yl) -2,5-diphenyltetrazolium bromide (MTT) Method}

This method is based on the principle of the cleavage of the MTT tetrazolium ring in active mitochondria. In this method, cultured live cells can be detected colorimetrically and quantitatively. The MTT method, first described by Mosmann and later developed, is a practical method used to determine cell viability. ${ }^{35}$

MTT is a substance that is actively absorbed into cells and is reduced to colored water-insoluble form due to activity in mitochondria. The MTT reduction feature of cells is considered a measure of cell viability. The density of the dye obtained as a result of MTT analysis correlates with the number of live cells. This method was used to detect the presence of living cells to demonstrate the effectiveness of the chemical compounds at different concentrations against SARS-CoV-2. As viral replication would decrease the live-cell ratio, a detected decrease in cell viability was indicated as increased viral reproduction.

In the MTT assay, the decrease in cell viability was associated with increased viral replication, whereas high cell viability was considered as an indicator of antiviral activity. For this purpose, seawater at different concentrations was added to the SARS-CoV-2 inoculated cell lines and was incubated for 96 hours in an incubator with $5 \%$ carbon dioxide at $37^{\circ} \mathrm{C} .10 \mu \mathrm{l}$ of MTT was added to each well, and the plates were incubated for 4 hours under the same conditions. Absorbance measurements were made at $570 \mathrm{~nm}$ on a spectrophotometer.

\section{Real-Time PCR}

SARS-CoV-2 replication in cell culture was verified by the Real-Time PCR method. Compared to the control group using the Real-Time PCR method, the presence or increase of viral replication was described as an increased number of viral copies. Viral RNA extraction was performed using a commercial kit under the commercial kit procedure. In the studies, the SYBR-Green RT-qPCR method was performed in accordance with the QuantiTect SYBR-Green PCR kit (Qiagen) test procedure. The PCR cycle starts with an initial denaturation at $95^{\circ} \mathrm{C}$ for 15 minutes, followed by three steps of 45 cycles of $94^{\circ} \mathrm{C}$ for 15 seconds, annealing at $60^{\circ} \mathrm{C}$ for 30 seconds and elongation at $72^{\circ} \mathrm{C}$ for 30 seconds, and a final extension temperature of $72^{\circ} \mathrm{C}$ for 10 minutes. The Human $\beta$-actin gene (QuantiTect Primer Assays, Qiagen) was used as the reference gene. All reactions were tested in triplicate at different intervals. $^{36}$

\section{Cycle Threshold Value}

In isolation, "Ct" values provide a relative measure of the viral quantity in the sample. Different known quantities of standards were included in the same study and tested in parallel with viral cultures. Thus, the "Ct" value could potentially provide some measure of viral copies. ${ }^{37,38} \mathrm{An} 8$ to $10-\mathrm{fold}$ 
dilutions series was prepared from the culture filtrate for SARS-CoV-2. Five replicates of each dilution were tested in parallel. All replicates were detected at dilutions of $10^{-1}$ to $10^{-5} .39$

\section{Molecular docking studies}

Molecular modeling studies were conducted using Maestro 11.8 (Schrödinger, LLC, New York, NY) software. Possible ionization states and tautomers of the ligands were determined by LigPrep (Schrödinger, LLC, New York, NY). Then, all ligands were optimized using the conjugate gradient method with force field parameters MacroModel and OPLS3 (Schrödinger, LLC, New York, NY). ${ }^{40}$ After the proteins were downloaded from the RCSB Protein Database (www.rcsb.org) 41 , this version of Protein Preparation Wizard was used for docking studies (Epik, Prime, Impact: Schrödinger, LLC, New York, $\mathrm{NY}){ }^{42}$ In this process, unwanted structures in proteins were removed, hydrogen atoms and missing side-chain atoms were added, partial charges and bonds were assigned, ionization states, hydrogen, and disulfide bonds were formed. Active regions of proteins were determined for docking, and grid

maps of proteins were created using Maestro's receptor grid generation panel. Ligands were docked on these maps 100 times in extra precision mode using Glide (Schrödinger, LLC, NY) software. The poses obtained from docking were examined, and appropriate docking scores were determined, as shown in Table $1 .{ }^{43}$

\section{Declarations}

\section{Declaration of Competing Interest}

The authors declare that there are no conflicts of interests.

\section{References}

1. Lu, H. Drug treatment options for the 2019-new coronavirus (2019-nCoV). Biosci. Trends. 14( (1)), 69-71 https://doi.org/10.5582/BST.2020.01020 (2020).

2. Simsek, S. \& Unal, Y. A. Antiviral treatment of covid-19. Turk. J. Med. Sci. 50, 611-619 https://doi.org/10.3906/sag-2004-145 (2020).

3. Farooq, S., Ngaini, Z. \& S. \& Natural and Synthetic Drugs as Potential Treatment for Coronavirus Disease 2019 (COVID-2019). Chem. Afr. 4, 1-13 https://doi.org/10.1007/s42250-020-00203-x (2020).

4. Ayten, O., Ozdemir, C., Akturk, U. \& Sen, N. Potential treatment of COVID-19. Eurasian J. Pulmonol. 22, 35-44 https://doi.org/10.4103/ejop.ejop_61_20 (2020).

5. Drozdzal, S. et al. FDA approved drugs with pharmacotherapeutic potential for SARS-CoV-2 (COVID-19) therapy. Drug Resist. Updat. 53, 100719 https://doi.org/10.1016/j.drup.2020.100719 (2020).

6. Hoffmann, M. et al. SARS-CoV-2 Cell Entry Depends on ACE2 and TMPRSS2 and Is Blocked by a Clinically Proven Protease Inhibitor. Cell. 181( (2)), 271-2808 https://doi.org/10.1016/j.cell.2020.02.052 (2020).

7. Gao, J., Tian, Z., Yang, X. \& Breakthrough Chloroquine phosphate has shown apparent efficacy in treatment of COVID-19 associated pneumonia in clinical studies. Biosi. Trends. 14((1)), 72-73 https://doi.org/10.5582/BST.2020.01047 (2020).

8. Jean, S. S., Lee, P. I. \& Hsueh, P. R. Treatment options for COVID-19: The reality and challenges. J. Microbiol. Immunol. Infect. 53( (3)), 436-443 https://doi.org/10.1016/j.jmii.2020.03.034 (2020).

9. Yin, W. et al. Structural basis for inhibition of the RNA-dependent RNA polymerase from SARS-CoV-2 by remdesivir. Science. 368, 1499-1504 https://doi.org/10.1126/science.abc1560 (2020).

10. Polansky, H. \& Lori, G. Coronavirus disease 2019 (COVID-19): first indication of efficacy of Gene-Eden-VIR/Novirin in SARS-CoV-2 infection. Int. J. Antimicrob. Agents. 55, 105971 https://doi.org/10.1016/j.ijantimicag.2020.105971 (2020).

11. Tang, X. et al. Novel chalcone derivatives containing a 1,2,4-triazine moiety: Design, synthesis, antibacterial and antiviral activities. RSC Adv. 9 , 6011-6020 https://doi.org/10.1039/c9ra00618d (2019).

12. Wu, J. H., Wang, X. H., Yi, Y. H. \& Lee, K. H. Anti-AIDS agents 54. A potent anti-HIV chalcone and flavonoids from genus Desmos. Bioorg. Med. Chem. Lett. 13, 1813-1815 https://doi.org/10.1016/S0960-894X(03)00197-5 (2003).

13. Hassan, S. T. S., Masarcikova, M. \& Berchova, K. Bioactive natural products with anti-herpes simplex virus properties.J. Pharm. Pharmacol.67,1325-1336 82015). https://doi.org/10.1111/jphp.12436

14. Kiat, T. S. et al. Inhibitory activity of cyclohexenyl chalcone derivatives and flavonoids of fingerroot, Boesenbergia rotunda (L.), towards dengue-2 virus NS3 protease. Bioorg. Med. Chem. Lett. 16, 3337-3340 https://doi.org/10.1016/j.bmcl.2005.12.075 (2006).

15. Biradar, J. S., Sasidhar, B. S. \& Parveen, R. Synthesis, antioxidant and DNA cleavage activities of novel indole derivatives. Eur. J. Med. Chem. 45, 4074-4078 https://doi.org/10.1016/j.ejmech.2010.05.067 (2010).

16. Burmaoglu, S. et al. Design of potent fluoro-substituted chalcones as antimicrobial agents. J. Enzyme Inhib. Med. Chem. 32, 490-495 https://doi.org/10.1080/14756366.2016.1265517 (2017). 
17. Chiaradia, L. D. et al. Synthesis, biological evaluation, and molecular modeling of chalcone derivatives as potent inhibitors of Mycobacterium tuberculosis protein tyrosine phosphatases (PtpA and PtpB). J. Med. Chem. 55, 390-402 https://doi.org/10.1021/jm2012062 (2012).

18. de Mello, M. V. P. et al. A comprehensive review of chalcone derivatives as antileishmanial agents. Eur. J. Med. Chem. 150, 920-929 https://doi.org/10.1016/j.ejmech.2018.03.047 (2018).

19. Park, J. Y. et al. Chalcones isolated from Angelica keiskei inhibit cysteine proteases of SARS-CoV. J. Enzyme Inhib. Med. Chem. 31, 23-30 https://doi.org/10.3109/14756366.2014.1003215 (2016).

20. Anil, D. A. \& Polat, M. F. Synthesis and characterization of some novel fluoro and methoxy substituted chalcone derivatives via nucleophilic aromatic substitution. Org. Commun. 13,1-9 https://doi.org/10.25135/acg.oc.73.20.02.1555 (2020).

21. Keyaerts, E. et. al. Viral load quantitation of SARS-coronavirus RNA using a one-step real-time RT-PCR. Int. J. Infect. Dis. 10, 32-37 https://doi.org/10.1016/j.ijid.2005.02.003 (2006).

22. Tom, M. R. \& Mina, M. J. To Interpret the SARS-CoV-2 Test, Consider the Cycle Threshold Value. Clin. Infect. Dis. 71( (16)), 2252-2254 https://doi.org/10.1093/cid/ciaa619 (2020).

23. Singanayagam, A. et al. Gopal, Duration of infectiousness and correlation with RT-PCR cycle threshold values in cases of COVID-19, England, January to May 2020. Eurosurveillance, 25(32), 2001483(2020). https://doi.org/10.2807/1560-7917.ES.2020.25.32.2001483

24. Wu, F. et al. A new coronavirus associated with human respiratory disease in China. Nature. 579, 265-269 https://doi.org/10.1038/s41586-0202008-3 (2020).

25. Guo, Y. R. et al. The origin, transmission and clinical therapies on coronavirus disease 2019 (COVID-19) outbreak- An update on the status. Military Med. Res. 7, 11 https://doi.org/10.1186/s40779-020-00240-0 (2020).

26. Jin, Z. et al. Structure of Mpro from SARS-CoV-2 and discovery of its inhibitors. Nature. 582, 289-293 https://doi.org/10.1038/s41586-020-2223-y (2020).

27. Wu, C. et al. Analysis of therapeutic targets for SARS-CoV-2 and discovery of potential drugs by computational methods. Acta Pharm. Sin. B. 10, 766-788 https://doi.org/10.1016/j.apsb.2020.02.008 (2020).

28. Vijayakumar, B. G., Ramesh, D., Joji, A., Prakasan, J. \& Kannan, T. In silico pharmacokinetic and molecular docking studies of natural flavonoids and synthetic indole chalcones against essential proteins of SARS-CoV-2. Eur. J. Pharmacol. 886, 173448 https://doi.org/10.1016/j.ejphar.2020.173448 (2020).

29. Jácome, R., Becerra, P., de León, S. \& Lazcano, A. Structural Analysis of Monomeric RNA-Dependent Polymerases: Evolutionary and Therapeutic Implications. PLoS One. 10((9)), e0139001 https://doi.org/10.1371/journal.pone.0139001 (2015).

30. Gao, Y. et al. Structure of the RNA-dependent RNA polymerase from COVID-19 virus. Science. 368, 779-782 https://doi.org/10.1126/science.abb7498 (2020).

31. Yin, W. et al. Structural basis for inhibition of the RNA-dependent RNA polymerase from SARS-CoV-2 by remdesivir. Science. 368, 1499-1504 https://doi.org/10.1126/science.abc1560 (2020).

32. Ersan, R. H. et al. Head-to-head bisbenzazole derivatives as antiproliferative agents: design, synthesis, in vitro activity, and SAR analysis. Mol. Divers. Early Access. https://doi.org/10.1007/s11030-020-10115-0 (2020).

33. Cechinel-Filho, V., Vaz, Z., Zunino, L., Calixto, J. \& Yunes, R. Synthesis of xanthoxyline derivatives with antinociceptive and antioedematogenic activities. Eur. J. Med. Chem. 31((10)), 833-839 https://doi.org/10.1016/0223-5234(96)83978-X (1996).

34. Allahverdiyev, A., Duran, N., Ozguven, M. \& Koltas, S. Antiviral activity of the volatile oils of Melissa officinalis L. against Herpes simplex virus type2. Phytomedicine. 11, 657-661 https://doi.org/10.1016/j.phymed.2003.07.014 (2004).

35. Mosmann, T. Rapid Colorimetric Assay for Cellular Growth and Survival: Application to Proliferation and Cytotoxicity Assays. J. Immunol. Methods. 65((1-2)), 55-63 https://doi.org/10.1016/0022-1759(83)90303-4 (1983).

36. Corman, V. M. et al. Detection of 2019 novel coronavirus (2019-nCoV) by real-time RT-PCR. Eurosurveillance. 25 ( https://doi.org/10.2807/15607917.ES.2020.25.3.2000045 (2020). )

37. Keyaerts, E. et al. Viral load quantitation of SARS-coronavirus RNA using a one-step real-time RT-PCR. Int. J. Infect. Dis. 10, 32-37 https://doi.org/10.1016/j.ijid.2005.02.003 (2006).

38. Tom, M. R. \& Mina, M. J. To Interpret the SARS-CoV-2 Test, Consider the Cycle Threshold Value. Clin. Infect. Dis. 71( (16)), 2252-2254 https://doi.org/10.1093/cid/ciaa619 (2020).

39. Buchan, B. W. et al. Practical comparison of the BioFire FilmArray pneumonia panel to routine diagnostic methods and potential impact on antimicrobial stewardship in adult hospitalized patients with lower respiratory tract infections. J. Clin. Microbiol. 58(7), e00135-20(2020). https://doi.org/10.1128/JCM.00135-20

40. Algul, O., Ersan, R. H., Alagoz, M. A., Duran, N. \& Burmaoglu, S. An efficient synthesis of novel di-heterocyclic benzazole derivatives and evaluation of their antiproliferative activities. J. Biomol. Struct. Dyn. Latest article(2020). https://doi.org/10.1080/07391102.2020.1803966

41. Alagoz, M. A. New molecule design with in-silico methods for Covid-19 treatment. Bioorg. Med. Chem. Reports. 3, 32-40 https://doi.org/10.25135/acg.bmcr.23.20.08.1773 (2020). 
42. Temirak, A. et al. Synthesis, biological evaluation and docking studies of new 2-furylbenzimidazoles as antiangiogenic agents. Eur. J. Med. Chem. 87, 868-880 https://doi.org/10.1016/j.ejmech.2014.01.063 (2014).

43. Ersan, R. H. et al. Bisbenzoxazole Derivatives: Design, Synthesis, in Vitro Antimicrobial, Antiproliferative Activity, and Molecular Docking Studies. Polycycl. Aromat. Compd. Latest article(2020). https://doi.org/10.1080/10406638.2020.1852589

\section{Figures}

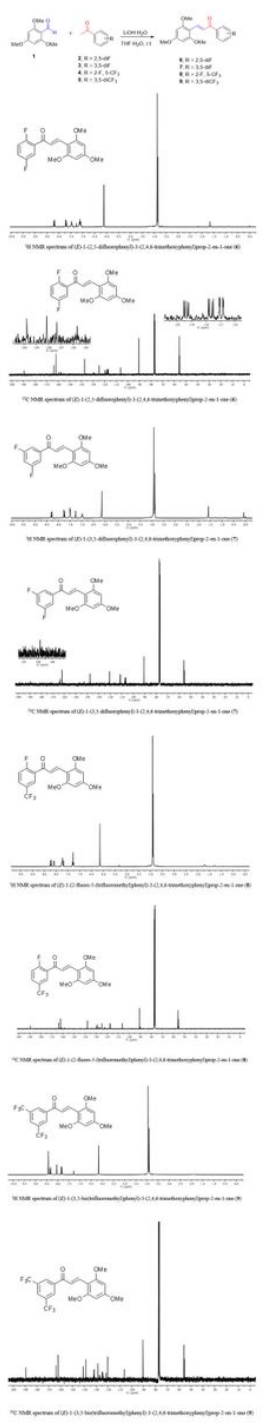

\section{Figure 1}

Preparation of fluoro/trifluoromethyl-substituted trimethoxy chalcones (6-9). 


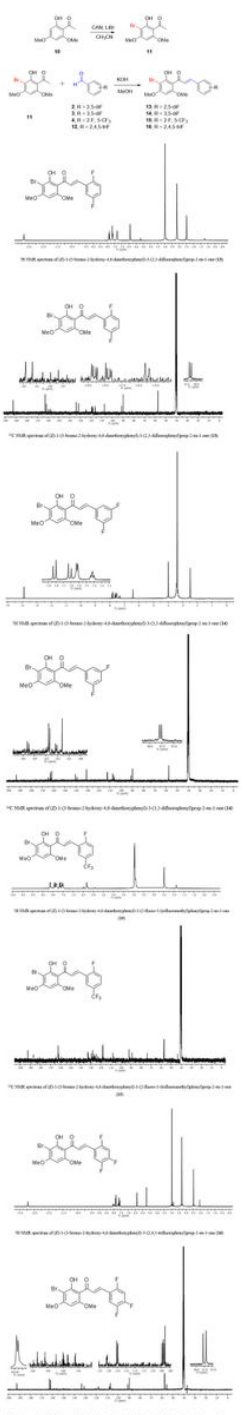

Figure 2

Preparation of bromo/fluoro/trifluoromethyl-substituted chalcones (13-16).
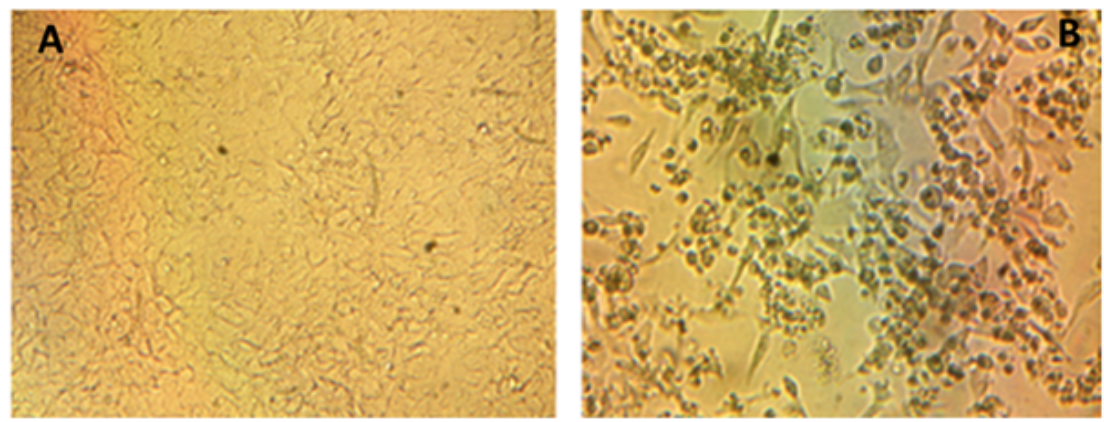

\section{Figure 3}

Cytopathological effects (CPE) of the SARS-CoV-2 in Vero E6 cells compared to the control group. A: Control group, B: Cytopathological changes caused by SARS-CoV-2. 


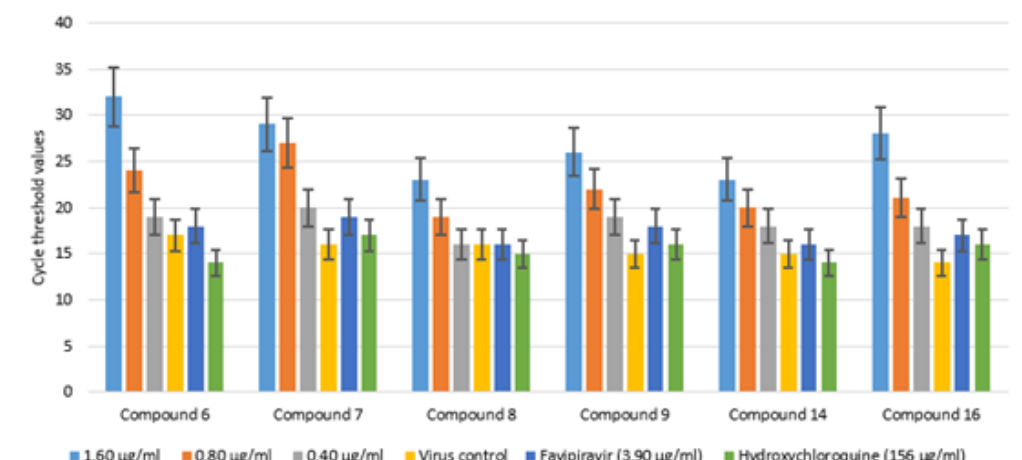

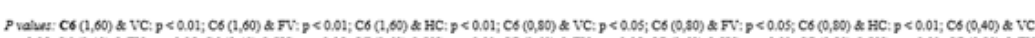

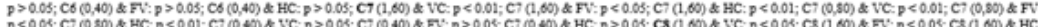

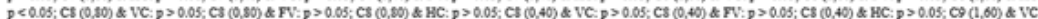

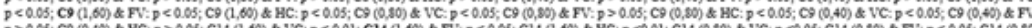

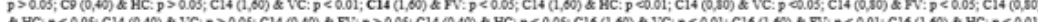

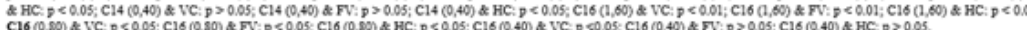

\section{Figure 4}

The effect of compounds $6,7,8,9,14$, and 16 at three different concentrations on SARS-CoV-2 replication compared to standard drugs.

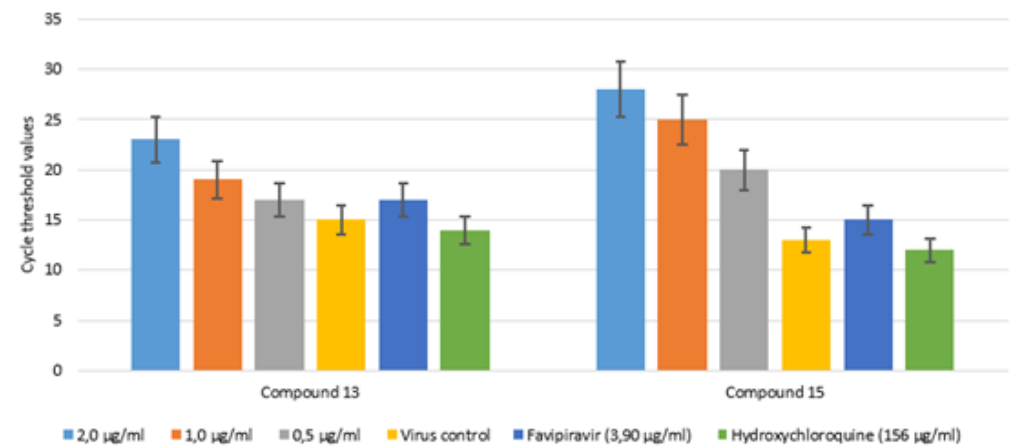

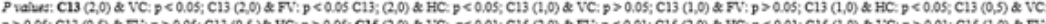

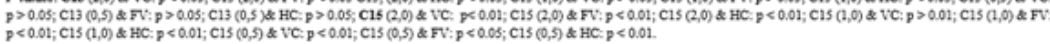

\section{Figure 5}

The effect of compounds 13 and 15 at three different concentrations on SARS-CoV-2 replication compared to standard drugs. 

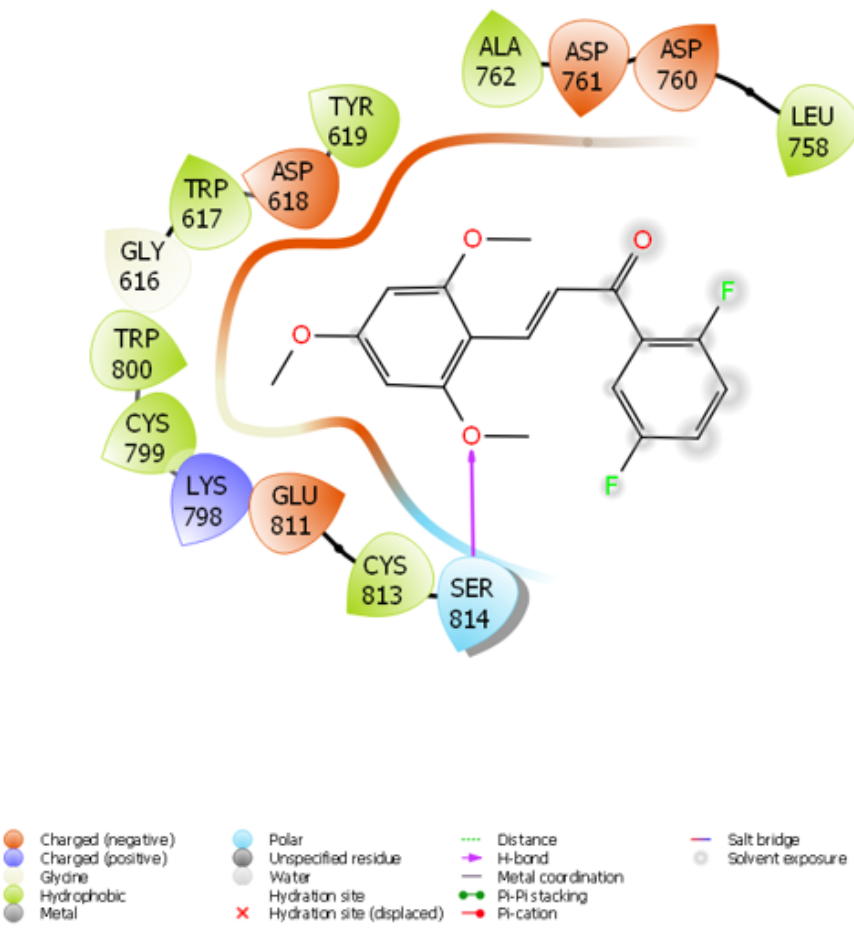

\section{Figure 6}

Interaction of compound 6 with the active site of $6 \mathrm{M} 71$.
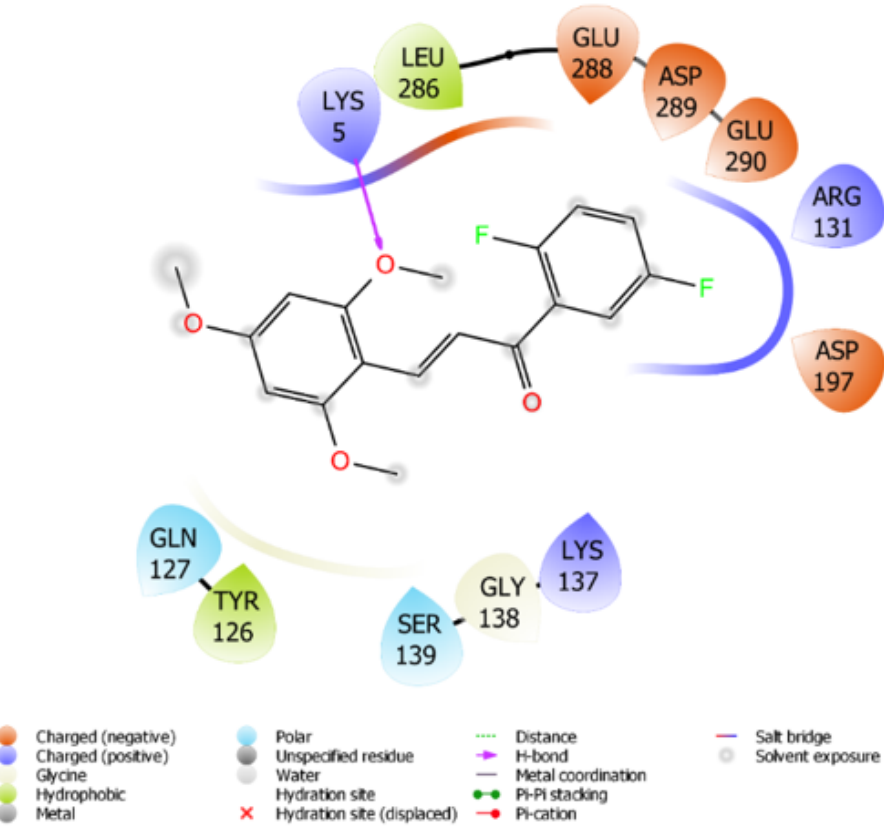

\section{Figure 7}

Interaction of compound 6 with the active site of $6 Y B 7$. 